\title{
Eksperimentasi Model Pembelajaran Problem Based Learning dan Konvensional pada Mata Pelajaran Matematika Ditinjau dari Problem Solving Skill Siswa
}

\author{
Agus Kristanto 1 , Suharno², Gunarhadi ${ }^{3}$ \\ kristanto.andaka@gmail.com
}

\begin{abstract}
This research aims to implement the Problem Based Learning model to improve students' problem solving skill which can be identified from the mathematics learning outcomes. Experimental research is conducted in Focus Independent School Primary School by taking a control class of 15 students and an experiment class of 16 students as the samples. The result of the pretest done at the beginning of the research shows that the experiment class hasa greater average score compared to the control class. The experiment class has an average score of 76.16 while other class reaches 75.64. By having different treatments; control class with conventional model and experiment class with problem based learning model, we may conlude that the students in the experiment class have produced better results than those in the control class. The average scores in both classes, control and experiment classes, are 78.50 and 82.03 with deviation standards of 13.120 and 12.623. The control class has a minimum score of 52.50 and maximum score of 97.50 , while the experiment class scores a minimum mark of 60 and maximum mark of 100. It shows that the problem based learning model is more effective to be implemented in the class than the conventional one. Students are given more chances to develop their problem solving skill by exploring for more knowledge and searching for solutions for the problems occurred.
\end{abstract}

Keywords: Problem Based Learning, Problem Solving Skill, Mathematics, Experimental Research

\footnotetext{
${ }_{1}^{1}$ Mahasiswa Magister Teknologi Pendidikan Universitas Sebelas Maret

2 Dosen Universitas Sebelas Maret Surakarta

3 Dosen Universitas Sebelas Maret Surakarta
} 


\section{PENDAHULUAN}

$\mathrm{P}$

erkembangan ilmu pengetahuan dan teknologi membawa paradigma baru tentang bagaimana cara mendesain sebuah sistem pembelajaran yang jauh lebih efektif dan efisien yang mampu memenuhi kebutuhan belajar setiap individu. Lahirnya era digital membawa perubahan pada cara siswa berpikir dan mengolah informasi.

Perubahan ini harus dimaknai sebagai sebuah tantangan untuk mengembangkan model pembelajaran di sekolah. Model pembelajaran yang dikembangkan harus mampu memberikan pengalaman belajar peserta didik untuk mengikuti dan memanfaatkan perkembangan ilmu pengetahuan, teknologi, dan seni.

Generasi abad 21 harus dibekali dengan kemampuan dasar sebagai berikut: ways of thinking, ways of working, tools for working, and skills for living in the world. UNESCO (2012) mendefinisikan beberapa keterampilan yang dibutuhkan generasi sekarang sebagai berikut:

1. Foundation Skills

Keterampilan dasar yang mencakup literacy dan numeracy skills yang diperlukan untuk melanjutkan jenjang studi ke tingkat yang lebih tinggi dan untuk memperoleh pekerjaan dengan kualitas yang lebih baik.

2. Transferable Skills

Keterampilan ini mencakup kemampuan memecahkan masalah, mengkomunikasikan ide dan informasi secara efektif, kreatif, kepemimpinan dan kewiraswastaan. Keterampilan ini dibutuhkan untuk meningkatkan kemampuan beradaptasi terhadap lingkungan.

3. Technical and Vocational Skills

Keterampilan khusus yang diperlukan untuk memenuhi persyaratan teknis pekerjaan tertentu, contoh: keahlian khusus dalam mengoperasikan komputer atau keahlian bercocok tanam.

Sekolah harus mampu memenuhi kebutuhan siswa untuk menghadapi persaingan global. Problem Solving Skills menjadi salah satu karakter yang harus dimiliki siswa untuk bertahan di pasar global. Pemilihan model pembelajaran harus mempertimbangkan keterampilan ini. Guru dituntut mampu memilih model pembelajaran yang tepat agar proses pembelajaran dapat berlangsung secara efektif.

Problem Based Learning (PBL), dalam bahasa Indonesia disebut sebagai Pembelajaran Berbasis Masalah (PBM), merupakan sebuah pendekatan pembelajaran yang menyajikan masalah kontekstual sehingga merangsang peserta didik untuk belajar. Dalam kelas yang menerapkan pembelajaran berbasis masalah, peserta didik bekerja dalam tim untuk memecahkan masalah dunia nyata (real world). Menurut Dewey (Mudjiman, 2011), proses belajar hanya akan terjadi kalau siswa dihadapkan kepada masalah dari kehidupan nyata untuk dipecahkan. Dalam membahas dan menjawab masalah, siswa harus terlibat dalam kegiatan nyata. Mudjiman berpendapat bahwa Problem Based Learning (PBL) merangsang siswa untuk menganalisis masalah, memperkirakan jawaban-jawabannya, mencari data, menganalisis data dan menyimpulkan jawaban terhadap masalah. Dengan kata lain model ini pada dasarnya melatih kemampuan memecahkan masalah melalui langkah-langkah sistematis.

Hal tersebut sesuai dengan pendapat Boud \& Feletti (1997) bahwa "PBL is a way of constructing and teaching courses using problems as the stimulus and focus for student activity". PBL diawali dengan masalah sebagai fokus utama Siswa dilatih untuk mengembangkan pengetahuan dan keterampilan melalui rangkaian masalah dan bagaimana menyelesaikannya. 
Tujuan yang ingin dicapai oleh PBL adalah kemampuan siswa untuk berpikir kreatif, analitis, sistematis, dan logis untuk menemukan alternatif pemecahan masalah melalui eksplorasi data secara empiris dalam rangka menumbuhkan sikap ilmiah. Trianto (2010) menyatakan bahwa tujuan PBL yaitu membantu siswa mengembangkan keterampilan berpikir dan keterampilan mengatasi masalah, belajar peranan orang dewasa yang autentik dan menjadi pembelajar yang mandiri. Sejalan dengan pendapat tersebut, pemecahan masalah merupakan salah satu strategi pengajaran berbasis masalah dimana guru membantu siswa untuk belajar memecahkan melalui pengalaman-pengalaman pembelajaran hands-on.

Berdasarkan beberapa pengertian di atas, dapat disimpulkan bahwa model Problem Based Learning adalah suatu pendekatan pembelajaran dimana siswa dihadapkan pada suatu masalah yang kemudian mengembangkan keterampilan-keterampilan melalui penyelidikan dan berpikir kritis sehingga dapat memandirikan peserta didik dalam belajar dan memecahkan masalah.

Pengajaran PBL terdiri dari lima tahapan utama yang dimulai dengan guru memperkenalkan siswa dengan situasi masalah dan diakhiri dengan penyajian dan analisis hasil kerja siswa. Kelima langkah tersebut adalah orientasi siswa pada masalah, mengorganisasi siswa untuk belajar, membimbing penyelidikan individual maupun kelompok, mengembangkan dan menyajikan hasil karya, menganalisis dan mengevaluasi proses pemecahan masalah.

Polya dalam Lumsdaine (1995) menyatakan bahwa skema pemecahan masalah matematika mencakup empat tahap, yaitu: identifikasi masalah, perencanaan solusi, pencarian langkah alternatif, pelaksanaan rencana dan pemeriksaan hasil.

Kemampuan kognitif dapat dipahami sebagai kemampuan anak untuk berpikir lebih kompleks serta kemampuan melakukan penalaran dan pemecahan masalah. Kognitif merupakan salah satu aspek penting dalam perkembangan peserta didik yang berkaitan langsung dengan proses pembelajaran dan sangat menentukan keberhasilan mereka di sekolah (Desmita, 2012).

Mengacu pada teori kognitif Piaget, pemikiran anak-anak usia sekolah dasar masuk dalam tahap pemikiran konkret-operasional (concrete operational thought), yaitu masa di mana aktivitas mental anak terfokus pada objek-objek yang nyata atau pada berbagai kejadian yang dialaminya.

Jensen (2008) berpendapat, "Pekerjaan otak yang paling penting adalah berpikir dan menyelesaikan masalah". Belajar berpikir adalah sebuah proses yang evolusioner. Dari waktu ke waktu makna dari materi yang disampaikan akan berkembang, pada akhirnya pembelajar akan mampu mengembangkan tingkat kemahirannya. Fokus utama yang menekankan pada kreativitas, keterampilanketerampilan kehidupan, serta memecahkan masalah menjadi alasan bahwa mengajari keterampilan berpikir kepada para pembelajar itu adalah sesuatu yang sangat bermanfaat dan produktif.

Problem Based Learning mendukung pelaksanaan pembelajaran yang berfokus pada pengembangan keterampilan pemecahan masalah. Jensen, Polya dan Dewey memberikan deskripsi pemecahan masalah sebagai salah satu aspek kognitif siswa yang harus dikembangkan melalui aktivitas pembelajaran yang diawali dengan masalah nyata. Siswa dituntut untuk berpikir kritis dan kreatif memecahkan masalah yang dihadapi.

\section{METODE PENELITIAN}

Penelitian ini dilaksanakan di Sekolah Dasar Focus Independent School yang beralamat di JI. K.S. Tubun 27, Manahan, Banjarsari, Kota Surakarta. Sampel yang digunakan sejumlah 31 siswa kelas VI; 15 siswa di kelas kontrol dan 16 siswa di kelas eksperimen. Data yang diperoleh adalah data kualitatif dan kuantitatif. Data kualitatif berupa data yang diperoleh dari hasil angket tanggapan siswa tentang 
model pembelajaran Problem Based Learning dan lembar keterlaksanaan sintaks pada uji lapangan operasional.

Data kuantitatif diperoleh dari data hasil tes awal (pretest) dan tes akhir (posttest), LO psikomotorik, dan LO afektif. Instrumen yang digunakan untuk mengumpulkan data dalam penelitian ini adalah: a) lembar validasi; b) angket tanggapan siswa dan guru terhadap model pembelajaran Problem Based Learning; c) LO afektif, LO psikomotorik, LO keterlaksanaan sintaks, serta; d) tes kognitif/ posttest. Teknik analisis kualitatif digunakan untuk mengolah data-data yang diperoleh dari reviewer para ahli, ujicoba produk, dan ujicoba pemakaian berupa tanggapan, masukan, kritik dan saran yang digunakan untuk merevisi produk. Pengolahan data menggunakan teknik deskriptif kualitatif. Analisis kuantitatif digunakan untuk mengolah data yang diperoleh dalam bentuk persentase. Teknik persentase digunakan untuk menyajikan data yang merupakan frekuensi atas tanggapan subjek uji coba terhadap model pembelajaran Problem Based Learning.

\section{HASIL DAN PEMBAHASAN}

Penelitian dilakukan pada 31 siswa, kelas kontrol sejumlah 15 siswa dengan menggunakan model pembelajaran konvensional, dan kelas eksperimen sejumlah 16 siswa dengan menggunakan model pembelajaran Problem Based Learning.

Instrumen penelitian berupa tes berbentuk pilihan ganda sebanyak 40 soal. Pretest dilakukan untuk mengetahui keadaan awal adakah perbedaan antara kelompok eksperimen dan kelompok kontrol. Hasil pretest menunjukkan bahwa nilai rata-rata siswa di kelas kontrol adalah 75,64 dan nilai rata-rata siswa di kelas eksperimen adalah 76,16. Kelas eksperimen kemudian diberi perlakuan menggunakan model pembelajaran Problem Based Learning, sedangkan kelas kontrol tetap menggunakan model pembelajaran konvensional. Setelah perlakuan di kedua kelas, siswa diberikan posttestuntuk mengukur pengaruh perlakuan di kelas eksperimen. Berikut data hasil posttest:

Tabel 1. Nilai Posttest

\begin{tabular}{ccc}
\hline Nilai & Kelas Kontrol & Kelas Eksperimen \\
\hline Nilai rata-rata & 78,50 & 82,03 \\
Nilai maksimum & 100 & 97,50 \\
Nilai minimum & 60,00 & 52,50 \\
Standar deviasi & 13,120 & 12,623 \\
\hline
\end{tabular}

Diagram berikut menunjukkan nilai siswa di kelas kontrol dan kelas eksperimen.

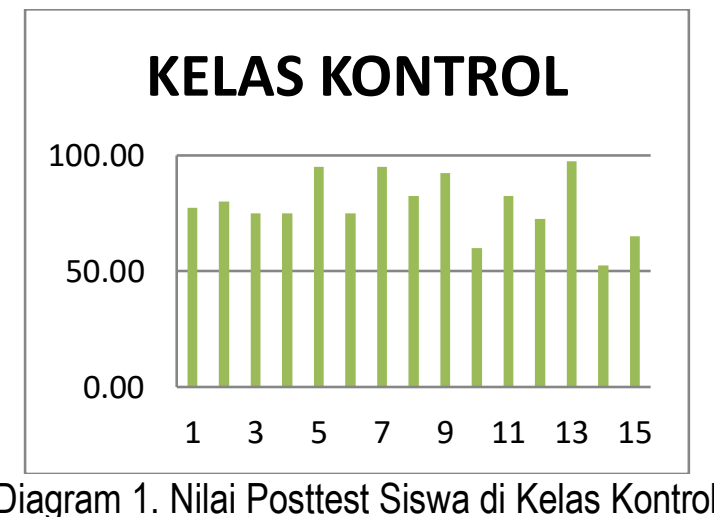




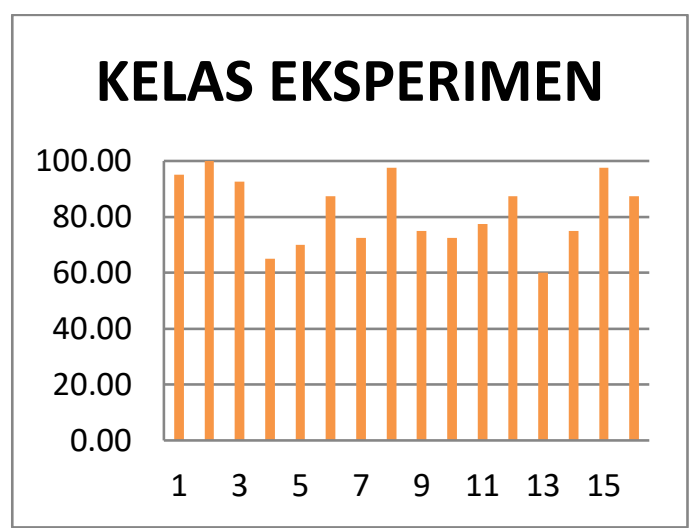

Diagram 2. Nilai Posttest Siswa di Kelas Eksperimen

Data menunjukkan bahwa peningkatan keterampilan memecahkan masalah pada siswa yang menggunakan model pembelajaran Problem Based Learning adalah lebih tinggi dibanding siswa yang menggunakan model pembelajaran konvensional. Analisis tingkat kesukaran butir soal menunjukkan bahwa butir soal no. 4, 16, 18, 19, 22, 24, 30, 32, 34, 37 dan 40 termasuk kategori sedang dengan indeks tingkat kesukaran antara $0,30-0.70$. Butir soal yang lain termasuk kategori mudah dengan indeks lebih dari 0,70 .

Model pembelajaran Problem Based Learning merupakan model pembelajaran yang efektif, karena pembelajaran berpusat pada siswa. Siswa dituntut untuk secara aktif mengembangkan pengetahuannya dan menemukan penyelesaian dari masalah yang diajukan.

\section{KESIMPULAN}

Model pembelajaran Problem Based Learning merupakan model pembelajaran yang efektif untuk meningkatkan Problem Solving Skill siswa. Data hasil penelitian menunjukkan bahwa siswa yang diberikan perlakuan menggunakan model pembelajaran Problem Based Learning menunjukkan peningkatan hasil belajar yang lebih bagus dibanding siswa yang diberikan perlakuan dengan menggunakan model pembelajaran konvensional.

\section{SARAN-SARAN}

Pengembangan model pembelajaran yang mampu memenuhi kebutuhan siswa untuk survive di abad 21 sangat mutlak diperlukan. Hasil penelitian ini memberikan satu gambaran tentang model pembelajaran yang lebih efektif dilakukan di era modern. Siswa seharusnya diberi ruang untuk mengembangkan diri secara aktif memecahkan setiap masalah yang dia hadapi. Setiap pendidik hendaknya memiliki ruang untuk selalu belajar mengembangkan diri guna mendukung keberhasilan pendidikan di Indonesia.

\section{DAFTAR PUSTAKA}

Boud, D., \& Feletti, G. (1997). The Challenge of Problem Based Learning. London: Kogan Page

Desmita. (2012). Psikologi Perkembangan Peserta Didik: Panduan bagi Orang Tua dan Guru dalam Memahami Psikologi Anak Usia SD, SMP dan SMA. Bandung: PT Remaja Rosdakarya

Hayat, B., \& Yusuf, S. (2010). Benchmark Internasional Mutu Pendidikan. Jakarta: PT Bumi Aksara 
Jensen, E. (2008). Brain-Based Learning: Pembelajaran Berbasis Kemampuan Otak, Cara Baru dalam Pengajaran dan Pelatihan. (Terjemahan). Yogyakarta: Pustaka Pelajar

Lumsdaine, E. (1995). Creative Problem Solving: Thinking Skills for Changing World. Singapore: McGraw-Hill Inc.

Mudjiman, H. (2011). Belajar Mandiri: Pembekalan dan Penerapan. Surakarta: UNS Press dan LPP UNS

Sugiyono. (2012). Metode Penelitian Kuantitatif, Kualitatif, dan R \& D. Bandung: Alfabeta

Trianto. (2010). Mengembangkan Model Pembelajaran Tematik. Jakarta: PT Prestasi Pustaka

UNESCO. (2012). The EFA Global Monitoring Report: Youth and Skills, Putting Education to Work. France: UNESCO Publishing 